\title{
Risk Assessment of Heavy Metals and Pesticides in Honey From Sicily (Italy)
}

\author{
Clara Naccari $^{1}$, Andrea Macaluso ${ }^{2}$, Giuseppe Giangrosso ${ }^{2}$, Francesco Naccari ${ }^{3} \&$ Vincenzo Ferrantelli ${ }^{2}$ \\ ${ }^{1} \mathrm{PhD}$ - Post Doc in Toxicology, University of Messina, Italy \\ ${ }^{2}$ Institute of Experimental Zooprophylaxy of Sicily “A. Mirri”, Palermo, Italy \\ ${ }^{3}$ Department of Veterinary Science, University of Messina, Italy \\ Correspondence: Clara Naccari, PhD - Post Doc in Toxicology, University of Messina, Polo SS. Annunziata, \\ I-98168 Messina, Italy. E-mail: cnaccari@unime.it
}

Received: January 14, 2014 Accepted: March 5, 2014 Online Published: March 25, 2014

doi:10.5539/jfr.v3n2p107 URL: http://dx.doi.org/10.5539/jfr.v3n2p107

\begin{abstract}
Honey, obtained by the honeybee (Apis mellifera) from nectar plants, with different composition according to floral sources, regional and climatic conditions, is widely consumed for its nutritional value and various properties. It could be considered a bio-indicator of environmental pollution to assess the presence of metals, naturally present in soil, and pesticides, widely used in agricultural practices. Actually no specific legislation on honey's metals and pesticides content exists. The aim of this study was to evaluate the presence of toxic metals $(\mathrm{Pb}$ and $\mathrm{Cd})$ and insecticides (organochlorines, organophosphates, pyrethrins and pyrethroids) in carob, chestnut and eucalyptus honey samples from Sicily and carried out a risk assessment to dietary intake of these contaminants. The results obtained showed low residual levels of $\mathrm{Pb}\left(0.1709 \pm 0.078 \mathrm{mg} \mathrm{kg}^{-1}\right)$ and $\mathrm{Cd}(0.0153 \pm$ $\left.0.004 \mathrm{mg} \mathrm{kg}^{-1}\right)$ while the concentrations of all pesticides analyzed were under the LOD $\left(<0.01 \mathrm{mg} \mathrm{kg}^{-1}\right)$. To explain the source of metals contamination in honey, the analytical investigation was conducted also in carob (Ceratonia siliqua L.), chestnut (Castanea sativa) and eucalyptus (Eucalyptus globules Labill.) powders, from which nectar honey is produced, confirming the presence of $\mathrm{Pb}$ and $\mathrm{Cd}$ concentrations with statistically significant differences $(\mathrm{P}<0.05$ and $\mathrm{P}<0.01)$ in all three types. The risk assessment, evaluated through the Target Hazard Quotient (THQ) and confirmed also by EFSA Provisional Tolerable Weekly Intake (PTWI), showed that metals daily intake through Sicilian honey consumption is not likely to cause deleterious effect for consumers.
\end{abstract}

Keywords: honey, risk assessment, intake, heavy metals, pesticides

\section{Introduction}

Honey is the natural sweet substance produced by honey bees (Apis mellifera and Apis dorsata fabricious) from the nectar of plants or from secretions of living parts of plants or excretions of plant sucking insects on the living parts of plants, which the bees collect, transform by combining with specific substances of their own, deposit, dehydrate, store and leave in the honey comb to ripen and mature (Codex, 2001). It consists essentially of different sugars, predominantly fructose and glucose as well as other substances such as organic acids, enzymes and solid particles derived from honey collection (Codex, 2001). Honey contains also several other compounds in traces, like proteins and enzymes, amino acids, pigments, substances responsible of its flavor and aroma, acids, alcohols and vitamins chrysin, pinobanksin, vitamin $\mathrm{C}$, catalase and pinocembrin, functioning as antioxidants (Stankovska, Stafilov, \& Šajn, 2008). There are also same essential elements (P, Fe, Al, Mg, Cu, Mn, Si, Cl, Ca, $\mathrm{K}$ and Na), natural constituents of the soil (Matei, Birghila, Dobrinas, \& Capota, 2004), which through plant's root system are transported to the nectar. The color of honey varies from nearly colorless to dark brown while the consistency can be fluid, viscous or partly to entirely crystallized (Codex, 2001).

Honey is a typical local product, its composition, flavor and aroma derived from the plant origin utilized by the bees, as well as regional and climatic conditions (Mendes, Proença, Ferreira, \& Ferreira, 1998; Singh \& Bath, 1997). The specific composition of any batch of honey and the possible presence of contaminants are dependent on the crops surrounding the beehive (Kujawski \& Namiesnik, 2008; Aliferis, Tarantilis, Harizanis, \& Alissandrakis, 2010). Honey could be considered an bio-indicator used for assessing the presence of 
environmental contaminants, like metals and pesticides (Conti \& Botrè, 2001).

Metal contamination of honey could be of environmental origin, as result of various anthropic activities (agricultural practice, industries, waste dump, etc.) (Przybylowsky \& Wilczyńska, 2001; Tuzen \& Soylak 2005; Stankovska, 2008; Özcan \& AL Juhaimi, 2011). Pesticides contamination, instead, could be of environmental source, as OCs, piretrines and piretroids used for plant treatment in agriculture practice (Thompson, 2010), and of apicultural origin, as acaricides and organophosphorus pesticides (OPPs) used for the control of Varroa jacobsonie and Ascosphera apis (Tsipi, Triantafyllou, \& Hiskia, 1999), pesticides for wax moth and small hive beetle control, antibiotics and other drugs for the treatment of bee disease and migration from wax to honey (Blasco, Vazquez-Roig, Onghena, Masia, \& Picó, 2011; Das \& Kaya, 2009). Particularly, pesticides used in crop production, applied as sprays, soil drenches, seed treatments or granules, may result in residues in the growing plant and in substrates attractive to honey bees, e.g. nectar, pollen or aphid honeydew, and can reduce the acreages of useful plants for the bee activity (Karise, Viik, \& Mand, 2007). Honey bees may be poisoned when they feed on nectar or pollen contaminated by pesticides or when they fly through a cloud of pesticide dust or spray or walk on treated parts of plant. Sometimes, colonies in the hives can be directly affected but most commonly field bees are killed or have their physiological functions altered.

Actually no specific legislation exists on maximum residual limits (MRLs) of heavy metals and pesticides in honey (Regulation EC 396/2005; Food Standard Agency: The honey Regulations 2003). Regulation EU 1999 has fixed in honey a MRL only for three acaricides, amitraz, coumaphos and cymiazole, of $0.2,0.1$ and $1 \mathrm{mg} / \mathrm{kg}$, respectively. Recently, the Regulation CE 37/2010 fixed, among the pesticides agents, a maximum limit only for Amitraz $\left(200 \mu \mathrm{g} \mathrm{kg}^{-1}\right)$ and for coumaphos $\left(100 \mu \mathrm{g} \mathrm{kg}^{-1}\right)$ and established, instead, for Flumethrin and Tau-fluvalinate no maximum residual levels required. Therefore, the monitoring on honey safety is very important because few MRLs of xenobiotics were fixed for this food and this makes difficult to discuss the toxicological importance of residues and causes problems in the international marketing and trade of this product (Choudhary \& Sharma, 2008).

Considering that honey is widely consumed by most people, especially in children, ill and old persons diet, for its nutritional value and for various health effects (antibacterial, antimutagenic and probiotic properties), in this study the presence of toxic metals $(\mathrm{Pb}$ and $\mathrm{Cd}$ ) and pesticides (organochlorines, organophosphates, pyrethrins and pyrethroids) was evaluated in carob, chestnut and eucalyptus honey samples from Sicily. In addition, a risk assessment due to dietary intake of these contaminates was carried out through Target Hazard Quotient (THQ) (US-EPA 2000) and Provisional Tolerable Weekly Intake (PTWI) percentage calculation (JEFCA, 1999) in all honey samples.

\section{Materials and Methods}

\subsection{Reagents and Chemicals}

Nitric acid $65 \%$ and ultrapure water for analysis of trace metals were provided by Suprapur (Carlo Erba-Italy). Hydrochloric acid 37\% was obtained from Prolabo-VWR-BDH (France). Standard stock solutions of $\mathrm{Pb}$ and $\mathrm{Cd}$ (1000 ppm) (99\% minimum purity) were provided by MERCK (Darmstand Germany).

Acetonitrile and deionized water (for pesticide residue analysis grade), for chromatographic analysis were provided by Baker (Mallinckrodt Backer, Milan, Italy).

Pesticides standard solutions (99\% minimum purity) of organochlorines (Aldrin, Azinphos Methyl, $\alpha$-BHC, $\beta$-BHC, $\delta$-BHC, $\gamma$-BHC (Lindane), Chlordane-cis, Chlordane-trans, DDD-o,p', DDD-p,p', DDE-o,p', DDE-p,p', DDT-o,p', DDT-p,p', Dieldrin, Endosulfan-alpha, Endosulfan-beta, Endosulfan-sulphate, Endrin, Endrin ketone, Heptachlor epoxide cis, Heptachlor epoxide trans, Heptachlor, Hexachlorobenzene, Metoxychlor), organophosphates (Chlorpyrifos, Methyl-Chlorpyrifos, Chlorthiophos, Coumaphos, Diazinon, Dichlorvos, Dimethoato, Ethion, Ethoprophos, Fenchlorphos, Fenitrothion, Malathion, Methidathion, Parathion, Parathion methyl, Protiofos), pyrethrins and pyrethroids (Bioallethrine, Cyfluthrine, Cypermethrine, Deltamethrin, Fenpropathrin, Lamba-cyalothrin, Permethrin cis, Permethrin trans, Tefluthrin) and internal standard solution of Fenclorphos were purchased by SIGMA Aldrich (Milan, Italy).

\subsection{Sampling}

The present investigation was conducted on 21 honey samples, collected by beekeepers from hives of the most important bees farms for production and marketing in various area of Sicily (Catania, Palermo, Ragusa, Agrigento), in April-May of year 2012. Honey samples were fresh, not pasteurized or subjected to any other thermal treatment gathered. All samples were unprocessed honeys of floral type and of different botanical origins, represented by Carob ( $\mathrm{n}=7$ samples), Chestnut $(\mathrm{n}=7$ samples) and Eucalyptus ( $\mathrm{n}=7$ samples). The floral 
origin of honey samples was directly characterized by the beekeeper in relation to the location where the beehives were situated. Twenty-one natural liquid honey samples collected $(100 \mathrm{~g})$ were stored in glass jars, kept at room temperature and in the dark until analysis. To better understand the possible origins of metals contamination in honey, further investigations were carried out on 8 samples of each different plant materials, exactly carob (Ceratonia siliqua L.), Chestnut (Castanea sativa) and Eucalyptus (Eucalyptus globulus Labill.) powder from the same areas of Sicily, from which nectar honey is produced. The plant materials were powdered with the aid of a mortar and pestle to provide uniformity in grain size and each samples was divided into three portions.

\subsection{Metals Analysis}

Honey samples were subjected to homogenization with a stainless steel blender (IKA T 10 Basic Ultra Turrax Homogenizer) and aliquots of $0.5 \mathrm{~g}$ were taken from each honey sample and submitted to digestion overnight with $5 \mathrm{ml}$ of $\mathrm{HNO}_{3}(65 \% \mathrm{v} / \mathrm{v})$.

For carob, chestnut and eucalyptus powders analysis, aliquots of $0.2 \mathrm{~g}$ were at first dried for five days in a desiccators and then digested overnight with $5 \mathrm{ml}$ of $\mathrm{HNO}_{3}(65 \% \mathrm{v} / \mathrm{v})$.

All samples of honey and carob were mineralized for $1 \mathrm{~h}$ in a microwave oven (model MDS-2000, CEM corporation, Matthews, NC, USA) with Teflon ${ }^{\mathrm{TM}}$ PFA reactors, equipped with a pressure regulation system. Analytical blanks were prepared in a similar manner without samples to check possible contamination during analysis. The samples and blank solutions were brought to a volume of $50 \mathrm{ml}$ with ultrapure water. All the glassware used during the analysis was previously treated with a dilute solution of $\mathrm{HNO}_{3}(0.1 \% \mathrm{v} / \mathrm{v})$ to prevent contamination and then rinsed with distilled water prior to use.

Metals determination was carried out by graphite furnace atomic absorption spectrometry (GFAAS) (AOAC, 1990) using an atomic absorption spectrophotometer (Analyst 800 Perkin Elmer), equipped with a single-element hollow cathode lamp $(283.3 \mathrm{~nm}$ for $\mathrm{Pb}, 228.8 \mathrm{~nm}$ for $\mathrm{Cd})$. The quantification was carried out using the external standard method and the calibration curve was constructed at five different concentrations (0.03-0.06-0.12-0.24-0.48 $\mu \mathrm{g} / \mathrm{l}) . \mathrm{Pb}$ and $\mathrm{Cd}$ concentrations $(\mathrm{Cc})$ in samples analyzed were calculated in $\mathrm{mg} / \mathrm{kg}$, according to the following formula:

$$
C_{c}=\frac{C_{s} \times V}{1000 \times p \times \bar{R}} \times D
$$

where

$\mathrm{Cc}: \mathrm{Pb}$ and $\mathrm{Cd}$ concentrations $\left(\mathrm{mg} \mathrm{kg}^{-1}\right)$ in samples

$\mathrm{Cs}$ : $\mathrm{Pb}$ and $\mathrm{Cd}$ concentrations ( $\left.\mathrm{mg} \mathrm{L}^{-1}\right)$ in samples solution, calculated by plotting on the straight line of setting

$\mathrm{V}$ : Volume $(\mathrm{mL})$ of sample solution

1000: Factor of conversion from $\mathrm{ml}$ to $\mathrm{L}$

P: Weight of sample (g)

D: Factor of dilution

R: Mean Recovery (\%)

The validation method was conducted according to AOAC guidelines (1990) (Table 1). To check the linearity, standard mixture at five concentrations (range $0.05-0.5 \mu \mathrm{g} \mathrm{mL}$ for $\mathrm{Pb}$; range $0.005-0.025 \mu \mathrm{g} \mathrm{mL}$ for $\mathrm{Cd}$ ) were analyzed in triplicate. The accuracy and repeatability of the method was determined by spike and recovery test. For both metal, recovery was measured in the matrix of 10 samples fortified at three concentrations (0.1-0.3-0.6 $\mathrm{mg} \mathrm{kg}{ }^{-1}$ for $\mathrm{Pb}$; $0.01-0.015-0.03 \mathrm{mg} \mathrm{kg}^{-1}$ for $\mathrm{Cd}$ ) within the range of measurement. Spike recoveries were repeated three times and the results are expressed as an average percentage of recovery $(98.7 \%$ for $\mathrm{Pb} ; 100 \%$ for Cd).

The limit of detection (LOD) and the limit of quantification (LOQ) were calculated following AOAC International (1994). The specificity was confirmed by analysis of blank samples (with no detectable levels of metals). Good laboratory practice (GLP) was applied throughout. 
Table 1. Linearity, limit of detection (LOD) and quantification (LOQ) and recovery percentages of analytical method for metal determination

\begin{tabular}{cccccc}
\hline Metals & Linearity $\left(\mathrm{R}^{2}\right)$ & LOD $\left(\mathrm{mg} \mathrm{kg}^{-1}\right)$ & LOQ $\left(\mathrm{mg} \mathrm{kg}^{-1}\right)$ & Recovery $(\%)$ & CV (\%) \\
\hline $\mathrm{Pb}$ & 0.998 & 0.0061 & 0.02 & 98.7 & 3.9 \\
$\mathrm{Cd}$ & 1.000 & 0.0014 & 0.01 & 100 & 2.5 \\
\hline
\end{tabular}

\subsection{Pesticides Analysis}

For pesticides extraction from food matrix, a Quechers method (Quick, Easy, Cheap, Effective, Rugged and Safe) was used (AOAC 2007). Aliquots of $5 \mathrm{~g}$ of honey were dissolved in $5 \mathrm{~mL}$ of deionized water, vortexed for 1 minute, added of $200 \mu \mathrm{l}$ of internal standard solution (Fenclorphos $5 \mathrm{mg} \mathrm{L}^{-1}$ ) and frozen for $2 \mathrm{~h}$ at $18{ }^{\circ} \mathrm{C}$. Samples were added with $10 \mathrm{~mL}$ of acetonitrile and extracted in SUPELCO dSPE citrate extraction tube by shaking for 1 minute and centrifuged for $5 \mathrm{~min}$ at $3000 \mathrm{rpm}$. Then $6 \mathrm{~mL}$ were transferred in dSPE PSA SPE Cleanup Tube by shaking for $30 \mathrm{sec}$ and centrifuged for $5 \mathrm{~min}$ at $3000 \mathrm{~g} / \mathrm{min}$. Finally, the organic phase was transferred into vials for chromatographic analysis. A Gas Chromatograph model Agilent $5975 \mathrm{C}$ (Santa Clara, USA), equipped with an CTC COMBO PAL auto-sampler, a MS single quadrupole detector and a HP-5 5\% Phenyl Methyl Siloxan column $(30 \mathrm{~m} \times 0.25 \mathrm{~mm}$, with $0.25 \mathrm{~lm}$ film thickness) (Agilent, Wilmington, USA) was used for identification and quantification of all pesticides. The injector and detector temperatures were $60{ }^{\circ} \mathrm{C}$ and $150{ }^{\circ} \mathrm{C}$, respectively. The carrier gas used was helium (99.9\%) at flow rate of $1.2 \mathrm{ml} / \mathrm{min}$ and the injection volume of $6 \mu \mathrm{l}$.

The column oven was temperature programmed from an initial value of $50{ }^{\circ} \mathrm{C}$ to $150{ }^{\circ} \mathrm{C}$ at a rate of $25^{\circ} \mathrm{C} / \mathrm{min}$ and then to $220^{\circ} \mathrm{C}(5 \mathrm{~min}$ hold $)$ at a rate of $2{ }^{\circ} \mathrm{C} / \mathrm{min}$ and then to $270{ }^{\circ} \mathrm{C}(10 \mathrm{~min}$ hold $)$ at a rate of $4{ }^{\circ} \mathrm{C} / \mathrm{min}$. The electronic impact (EI) source was $70 \mathrm{eV}$, the acquisition of spectra was performed in SIM analysis.

Quantitative evaluation of the pesticides residues was performed by the internal standard method using Fenclorphos at a concentration of $5 \mathrm{mg} / \mathrm{L}$ and the calibration curves were obtained by comparing the value of the areas of the specific peaks with their concentration. For every pesticide, four standard concentrations $(5,10,25$, $50 \mathrm{ng} \mathrm{mL}^{-1}$ ) were injected. Correlation coefficients were calculated automatically. Signal to noise $(\mathrm{S} / \mathrm{N})$ values were quantified for each standards. LODs were calculated from $\mathrm{S} / \mathrm{N}$ values by using the correction factors; for all pesticides analyzed the LOQ value was of $0.01 \mathrm{mg} \mathrm{kg}^{-1}$.

The precision and accuracy of the procedure was carried out by analysis of spike and recovery test. For quantity of recovery percentages, a total of $5 \mathrm{~g}$ honey sample was measured in a beaker, heated at $35^{\circ} \mathrm{C}$ in a water bath, cooled to room temperature and finally spiked with three amounts of standard mixtures pesticides $(25,50,75 \mathrm{ng}$ $\left.\mathrm{g}^{-1}\right)$. Recovery were detected in triplicate and the results were expressed as average percentage of recovery. The specificity was confirmed by analysis of blank samples, carried out as previously described for three determinations. Good laboratory practice (GLP) was applied throughout and procedural blanks were also analyzed. The parameters of the calibration method are reported in Table 2. 
Table 2. Linearity, limit of quantification (LOQ) of analytical method for pesticides determination and recovery

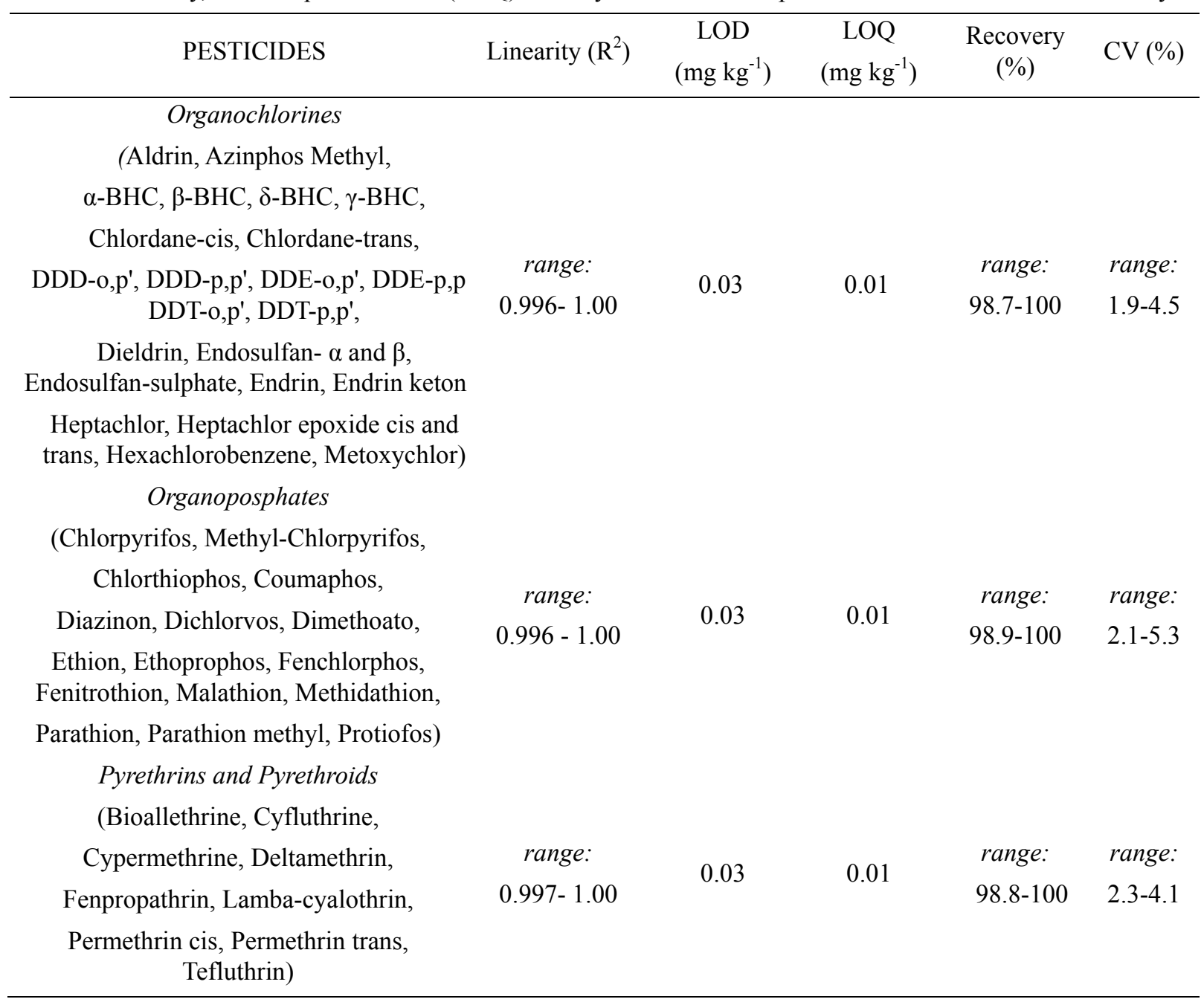

\subsection{Risk Assessment}

The assessment of health risks due to consumption of honey was evaluated through the Target Hazard Quotient (THQ), considered the ratio between exposure and the reference exposure dose. The THQ for $\mathrm{Cd}$ and $\mathrm{Pb}$ was determined following to the methodology described by US-EPA 2000 and calculated for an adult average body weight of $60 \mathrm{~kg}$ and considering a food ingestion rate of $1 \mathrm{~g} /$ day (Apitalia, 2013), according on the formula:

$$
T H Q=[(E F r \times E D t o t \times I F R \times C) /(R f D o \times B W a \times A T n)] \times 10^{-3}
$$

where:

$E F r$ : the exposure frequency (365 days/year);

EDtot: is the exposure duration (80 years for the Italian population) according to ISTAT 2013;

IFR: is the food ingestion rate $\left(\mathrm{g} \mathrm{day}^{-1}\right)$;

$C$ : is the concentration $\left(\mu \mathrm{g} \mathrm{g}^{-1}\right)$;

RfDo: is the oral reference dose $\left(\mu \mathrm{g} \mathrm{g}^{-1} \mathrm{day}^{-1}\right)$;

$B W a$ : is the adult body weight $(60 \mathrm{~kg})$;

$A T n$ : is the average time for non carcinogens (it is equal to EFr x EDtot).

\subsection{Statistical Analysis}

Data are expressed as mean values \pm S.D. of at least four determinations and statistically analyzed by one-way analysis of variance (ANOVA) and Student $t$ test. The statistical analysis were significant when $\mathrm{P}<0.05$. 


\section{Results}

The results obtained from honeys produced in Sicily showed only the presence of metals residual levels in all samples analyzed. Relating to pesticides, all organochlorines, organophosphates pyrethrins and pyrethroids compounds analyzed, instead, in honey samples were under the LOQ $\left(<0.01 \mathrm{mg} \mathrm{kg}^{-1}\right)$. Residual levels of metals found in honey samples are reported in Table 3 and it's possible to observe the presence of $\mathrm{Pb}$ concentrations $\left(0.1709 \pm 0.078 \mathrm{mg} \mathrm{kg}^{-1}\right)$ higher than $\mathrm{Cd}\left(0.0153 \pm 0.004 \mathrm{mg} \mathrm{kg}^{-1}\right)$ with difference statistically significant $(\mathrm{P}<$ 0.05). No significant differences were found in honey samples came from different provinces of Sicily. The comparative analysis of metal concentrations in honey of different floral origin (Figure 1) showed higher $\mathrm{Pb}$ levels in chestnut $\left(0.281 \pm 0.004 \mathrm{mg} \mathrm{kg}^{-1}\right)$ than carob $\left(0.0977 \pm 0.006 \mathrm{mg} \mathrm{kg}^{-1}\right)$ and eucalyptus $(0.131 \pm 0.005 \mathrm{mg}$ $\mathrm{kg}^{-1}$ ) with differences statistically significant $(\mathrm{P}<0.01$ and $\mathrm{P}<0.05$, respectively), while Cd concentrations were similar in all three types $\left(0.015 \pm 0.003 \mathrm{mg} \mathrm{kg}^{-1}\right.$ in carob; $0.019 \pm 0.004 \mathrm{mg} \mathrm{kg}^{-1}$ in chestnut; $0.010 \pm 0.005 \mathrm{mg}$ $\mathrm{kg}^{-1}$ in eucalyptus).

Table 3. Residual levels $\left(\mathrm{mg} \mathrm{kg}^{-1}\right)$ of $\mathrm{Pb}$ and $\mathrm{Cd}$ in honey samples from Sicily of different floral origin

\begin{tabular}{cccc}
\hline Samples & Floral type & $\mathrm{Pb}\left(\mathrm{mg} \mathrm{kg}^{-1}\right)$ & $\mathrm{Cd}\left(\mathrm{mg} \mathrm{kg}^{-1}\right)$ \\
\hline 1 & Carob & 0.125 & 0.008 \\
2 & Carob & 0.097 & 0.015 \\
3 & Carob & 0.108 & 0.015 \\
4 & Carob & 0.089 & 0.014 \\
5 & Carob & 0.078 & 0.018 \\
6 & Carob & 0.087 & 0.019 \\
7 & Carob & 0.095 & 0.016 \\
8 & Chestnut & 0.31 & $<\mathrm{LOQ}$ \\
9 & Chestnut & 0.39 & 0.018 \\
10 & Chestnut & 0.25 & 0.024 \\
11 & Chestnut & 0.38 & 0.02 \\
12 & Chestnut & 0.11 & $<\mathrm{LOQ}$ \\
13 & Chestnut & 0.28 & 0.012 \\
14 & Chestnut & 0.28 & 0.021 \\
15 & Eucalyptus & 0.15 & 0.011 \\
16 & Eucalyptus & 0.09 & 0.008 \\
17 & Eucalyptus & 0.13 & 0.015 \\
18 & Eucalyptus & 0.16 & 0.017 \\
19 & Eucalyptus & 0.11 & 0.013 \\
20 & Eucalyptus & 0.15 & 0.018 \\
21 & Eucalyptus & 0.12 & 0.009 \\
\hline & $M . V . \pm S . D$. & $0.1709 \pm 0.068^{*}$ & $0.0153 \pm 0.004$ \\
\hline
\end{tabular}

$* \mathrm{P}<0.05$. LOD for $\mathrm{Pb} \leq 0.02$. LOD for $\mathrm{Cd} \leq 0.01$. 


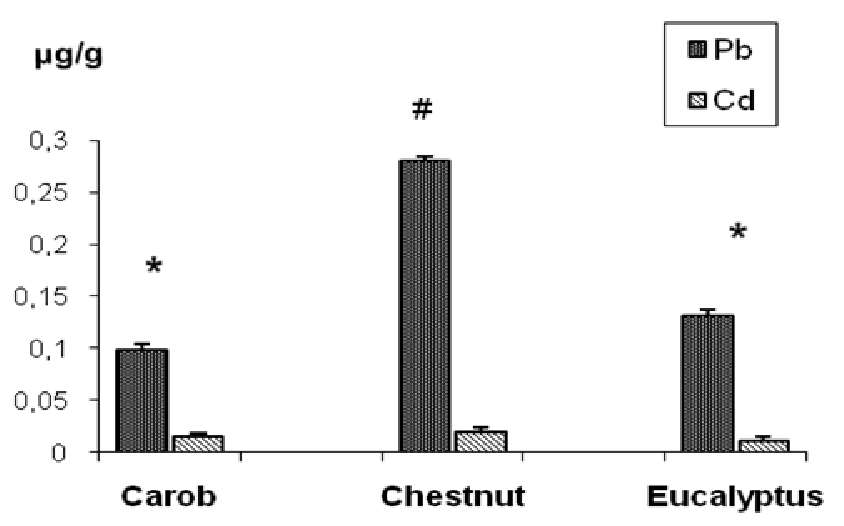

$* \mathrm{P}<0.05 ; \# \mathrm{P}<0.01$

Figure 1. Comparative analysis of $\mathrm{Pb}$ and $\mathrm{Cd}$ content in honey samples of different floral origin (Carob, Chestnut and Eucalyptus) from Sicily

Metals analysis on carob, chestnut and eucalyptus powder samples, instead, showed the presence of higher residual levels $(\mathrm{P}<0.05)$ of $\mathrm{Pb}$ and $\mathrm{Cd}$, with mean values of $0.18 \pm 0.040 \mathrm{mg} \mathrm{kg}^{-1}$ (w.d.) and $0.07 \pm 0.0021 \mathrm{mg}$ $\mathrm{kg}^{-1}$ (w.d.) for carob, $0.41 \pm 0.022 \mathrm{mg} \mathrm{kg}^{-1}$ (w.d.) and $0.12 \pm 0.0015 \mathrm{mg} \mathrm{kg}^{-1}$ (w.d.) for chestnut and $0.39 \pm 0.026$ $\mathrm{mg} \mathrm{kg}^{-1}$ (w.d.) and $0.09 \pm 0.0015 \mathrm{mg} \mathrm{kg}^{-1}$ (w.d.) for eucalyptus, respectively. In addition, a comparative analysis among $\mathrm{Pb}$ and $\mathrm{Cd}$ content in carob, chestnut and eucalyptus honey and powder samples showed differences statistically significant $\mathrm{P}<0.05$ for $\mathrm{Pb}$ and $\mathrm{P}<0.01$ for $\mathrm{Cd}$ levels (Figure 2).
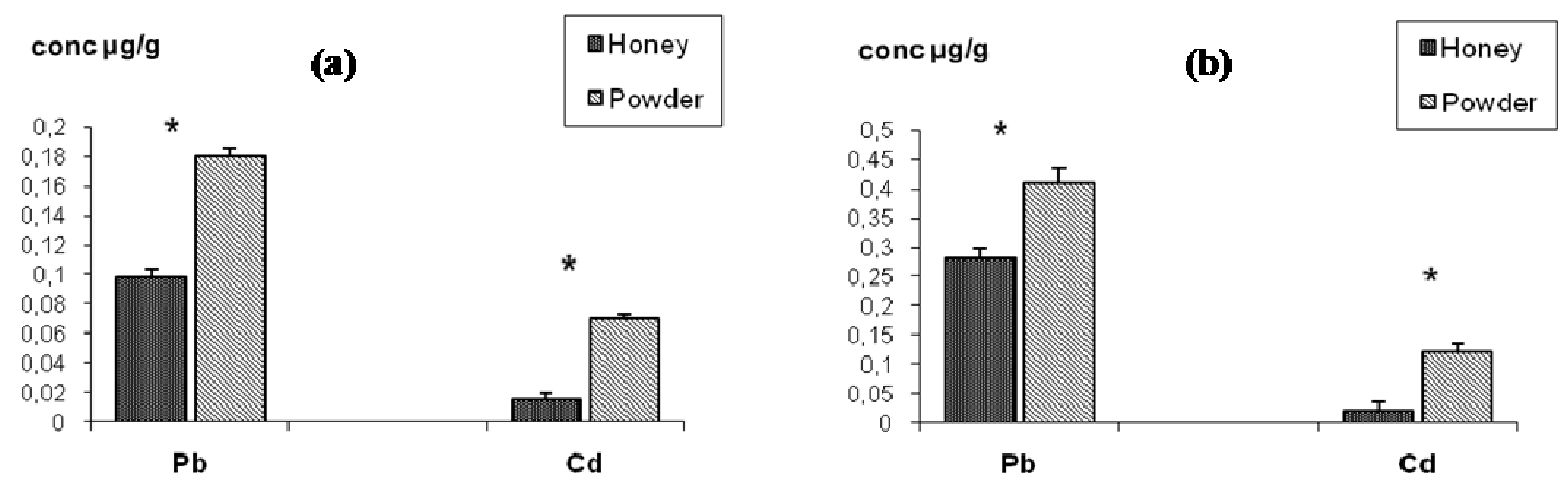
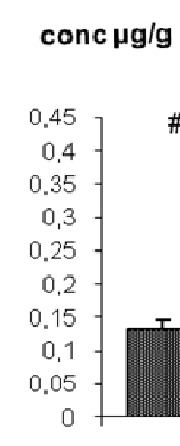

(c)

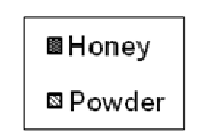

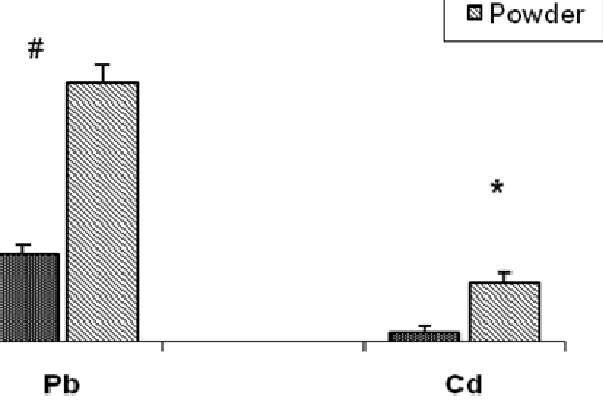

$* \mathrm{P}<0.05 ; \# \mathrm{P}<0.01$

Figure 2. Comparitive analysis of $\mathrm{Pb}$ and $\mathrm{Cd}$ content in honey and powder samples of (a) Carob, (b) Chestnut and (c) Eucalyptus from Sicily 
The risk assessment has been evaluated by the Target Hazard Quotient, calculated using the RfDo, an estimation of the daily exposure to which the human population is likely to be without any appreciable risk of deleterious effects during a lifetime. The European Protection Agency (EPA) has established a RfDo of $1 \times 10^{-3}$ for Cd and the THQ value obtained for this metal was $2.76 \times 10^{-7}$ in carob, $3.57 \times 10^{-7}$ in chestnut and $1.81 \times 10^{-7}$ in eucalyptus honey samples (Table 4). For Pb, instead, the EPA declined to set this value because it has found no evidence of a threshold below which a non harmful intake could be "allowed" (US-EPA 2004). In absence of this parameter, the THQ could be calculated taking in consideration the metal concentration in food and its official MRL (Maximum Residual Limit) but actually the European Commission has not established a specific MRL for $\mathrm{Pb}$ in honey, therefore, the Target Hazard Quotient was calculated only for cadmium.

Table 4. Residual levels ( $\mathrm{mg} / \mathrm{Kg}$ ) of $\mathrm{Pb}$ and $\mathrm{Cd}$ in honey samples of different floral origin from Sicily, expressed as provisional tolerable weekly intake (PTWI \%) and Target Hazard Quotient (THQ)

\begin{tabular}{|c|c|c|c|c|c|c|}
\hline \multirow[b]{2}{*}{ HONEY } & \multicolumn{3}{|c|}{$\mathrm{Pb}$} & \multicolumn{3}{|c|}{$\mathrm{Cd}$} \\
\hline & $\begin{array}{c}\text { Concentration } \\
\quad\left(\mathrm{mg} \mathrm{kg}^{-1}\right)\end{array}$ & $\begin{array}{c}P T W I \\
(\%)\end{array}$ & $T H Q$ & $\begin{array}{c}\text { Concentration } \\
\quad\left(\mathrm{mg} \mathrm{kg}^{-1}\right)\end{array}$ & $\begin{array}{c}P T W I \\
(\%)\end{array}$ & $T H Q$ \\
\hline $\begin{array}{c}\text { CAROB } \\
(n=8)\end{array}$ & $\begin{array}{c}0.0977 \pm 0.015 \\
(0.078-0.125)\end{array}$ & 7.82 & $* 1.76 \times 10^{-6}$ & $\begin{array}{c}0.0151 \pm 0.003 \\
(0.008-0.019)\end{array}$ & 12 & $2.76 \times 10^{-7}$ \\
\hline $\begin{array}{c}\text { CHESTNUT } \\
\qquad(\mathrm{n}=8)\end{array}$ & $\begin{array}{c}0.281 \pm 0.083 \\
(0.11-0.39)\end{array}$ & 22.4 & $* 5.1 \times 10^{-6}$ & $\begin{array}{c}0.0197 \pm 0.004 \\
(0.012-0.024)\end{array}$ & 15.2 & $3.57 \times 10^{-7}$ \\
\hline $\begin{array}{l}\text { EUCALYPTUS } \\
\qquad(\mathrm{n}=8)\end{array}$ & $\begin{array}{c}0.131 \pm 0.025 \\
(0.09-0.016)\end{array}$ & 10.48 & $* 2.37 \times 10^{-6}$ & $\begin{array}{c}0.0100 \pm 0.003 \\
(0.008-0.018)\end{array}$ & 8 & $1.81 \times 10^{-7}$ \\
\hline
\end{tabular}

* This value, calculated taking in consideration a proposed $\mathrm{MRL}$ for $\mathrm{Pb}$, is a speculation because no $\mathrm{RfDo}$ for $\mathrm{Pb}$ was fixed by EFSA.

\section{Discussion}

Metal concentrations found in honey samples in this study are lower than residual levels obtained by other author in honey from Turkey (Erbilir \& Erdogrul, 2005) and Spain (Frias et al., 2008), similar to that obtained in other region of Italy (Ruschioni et al., 2013; Perna, Simonetti, Intaglietta, Sofo, \& Gambacorta, 2012) but higher than in France (Lambert et al., 2012). Considering the different floral types, the comparative analysis of metals residual levels in our honey samples (Figure 1) showed higher levels of both $\mathrm{Pb}$ and $\mathrm{Cd}$ in chestnut honey vs eucalyptus (in accordance with Perna et al., 2012) and vs carob samples.

These low metal levels could be explained by mineral and trace element content in carob, chestnut and eucalyptus plant materials (Ayaz et al., 2009) from which nectar honey has been produced. These plants, in fact, could contribute to accumulation of trace heavy metals in their tissues, according to their different availability in the soil (Kabata-Pendias, 2004). Among metals, in particular, $\mathrm{Pb}$ is rather immobile in the soil and it is poorly translocated to the vegetative parts, while $\mathrm{Cd}$ is easily adsorbed; their presence reflect the environmental pollution trend. Moreover, the lower metals concentrations in carob, chestnut and eucalyptus honey than powder samples found in these investigation could be due to the filtering effect of bees in floral nectar (Chlebo, 2006).

The Joint FAO/WHO Expert Committee on Food Additives (JEFCA, 1999) set a limit for heavy metal intake based on body weight, indicating for an adult of $60 \mathrm{~kg}$ a "provisional tolerable weekly intake" (PTWI) of Pb at $0.025 \mathrm{mg} / \mathrm{kg} /$ week and of Cd at $0.007 \mathrm{mg} / \mathrm{Kg} /$ week. Recently, EFSA CONTAM Panel 2009 modified PTWI for $\mathrm{Cd}$ at $2.5 \mu \mathrm{g} \mathrm{kg}^{-1}$, confirmed in year 2011, and retired the PTWI. However, considering a weekly assumption of $20 \mathrm{~g}$ of honey, the results obtained correspond to a small percentage of PTWI ( $7.82 \%$ in carob, $22.4 \%$ in chestnut and 10.48 in eucalyptus for $\mathrm{Pb} ; 12 \%$ in carob, $15.2 \%$ in chestnut and 8.0 in eucalyptus for $\mathrm{Cd}$ ) (Table 4).

The THQ calculated according RfDo set by EFSA for Cd indicates that there is no carcinogenic risk, in fact THQs values below 1 indicates a level of exposure smaller than the reference dose (Table 4). For Pb there isn't actually a specific RfDo or the official MRL (Maximum Residual Limit) in honey, needed for THQ calculation. Recently, a proposed value of MRL for $\mathrm{Pb}$ is of $1 \mathrm{mg} / \mathrm{kg}$ and, considering this limit, the THQ value, for our samples, however results below 1 . Therefore it's possible to assume that metals daily intake through Sicilian honey consumption is not likely to cause any deleterious effect during lifetime in humans. 
The pesticides analysis, carried out according to the Quechers method for a simultaneous determination of different classes of compounds (organochlorines, organophosphates, pyrethrins and pyrethroids), showed the absence of residual concentrations in all honey samples. Similarly to our results, Bogdanov (2006) reported no measurable residues of insecticides in honey. Several investigations conducted on different types of honey and through various analytical methods (Buldini, Cavalli, Mevoli, \& Lal Sharma, 2001; Zhu et al., 2008; Zhang, Gao, Peng, Li, \& Zhou, 2011; Blasco et al., 2011) showed, instead, the presence of pyrethrins and pesticides in honey from India (Mukherjee, 2009) and Spain (Herrera et al., 2005), respectively. In another study on honey from Spain and Portugal, residues of 42 different pesticides were examined (Blasco et al., 2003; Blasco, Fernandez, Pico, \& Font, 2004) and most of the compounds found were organochlorines, like gamma-HCH, HCB and its isomers $\alpha-\mathrm{HCH}$ and $\beta-\mathrm{HCH}$, with concentrations ranging from 0.03 to $4.31 \mathrm{mg} \mathrm{kg}^{-1}$, but most of them were below $0.5 \mathrm{mg} \mathrm{kg}^{-1}$.

Considering the absence of pesticides (organoclorines, organophosphates, pyrethrins and pyrethroids) in our honey samples studied, the analysis of these compounds was not conducted in plant materials of carob, chestnut and eucalyptus. In addition, these plants are generally resistant to pests and do not need to be sprayed with pesticides (Batlle \& Tous, 1997).

The results of the present study, moreover, confirm that honey from Sicily represents a low risk of metals and pesticides exposure for consumer, in fact it makes a minimal contribution to $\mathrm{Pb}$ and $\mathrm{Cd}$ PTWI (Chlebo, 2006), with THQs values below 1, not dangerous for human health. The low metal levels found in all samples from bee-farms of various areas of Sicily are probably due to the small development of industrial activities while the absence of pesticides residues to traditional agricultural activities in this region (Schur \& Wallner, 2000).

\section{Conclusion}

These investigation shows the good quality and safety of honey produced in Sicily. The low metals content found and the absence of pesticides suggest a small environmental pollution in Sicilian areas where honey has been produces and the importance of traditional agricultural practices used. In addition, this study underlines that the honey could be also a valid "bio-indicator" of environmental pollution, considering that honeybees are exposed to heavy metals travelling long distances and to different pesticides used in agriculture. In conclusion, from these data it is possible hypothesize that honey produced in the most important bee-farms of various areas of Sicily could be consumed as "functional food" in children, old and ill persons diet without human risk.

\section{References}

Aliferis, K. A., Tarantilis, P. A., Harizanis, P. C., \& Alissandrakis, E. (2010). Botanical discrimination and classification of honey samples applying gas chromatography/mass spectrometry fingerprinting of $\begin{array}{lllll}\text { headspace volatile } & \text { compounds. }\end{array}$ http://dx.doi.org/10.1016/j.foodchem.2009.12.098

AOAC International. (1994). Peer-Verified Methods Program. Manual on Policies and Procedures (pp. 115-120). Gaitherburg, MD.

AOAC Official Method. (2007). Pesticide Residues in Foods by Acetonitrile Extraction and Partitioning with Magnesium Sulfate.

Association of Analytical Communities. (1990). Metals and other elements at trace levels in foods. Official Method Analitical AOAC, 1, 237.

Ayaz, F. A., Torun, H., Glew, R. H., Bak, Z. D., Chuang, L. T., Presley, J. M., \& Andrews, R. (2009). Nutrient Content of Carob Pod (Ceratonia siliqua L.) Flour Prepared Commercially and Domestically. Plant Foods Hum Nutr, 64, 286-292. http://dx.doi.org/10.1007/s11130-009-0130-3

Batlle, I., \& Tous, J. (1997). Carob tree: Ceratonia siliqua L. 1997. Promoting the conservation and use of underutilized and neglected crops. 17. Institute of Plant Genetics and Crop Plant Research, Gatersleben/International Plant Genetic Resources Institute, Rome, Italy.

Blasco, C., Vazquez-Roig, P., Onghena, M., Masia, A., \& Picó, Y. (2011). Analysis of insecticides in honey by liquid chromatography-ion trap-mass spectrometry: Comparison of different extraction procedures. $J$. Chromatogr A, 1218, 4892- 4901. http://dx.doi.org/10.1016/j.chroma.2011.02.045

Blasco, C., Fernandez, M., Pico, Y., \& Font, G. (2004). Comparison of solid-phase microextraction and stir bar sorptive extraction for determining six organophosphorus insecticides in honey by liquid $\begin{array}{llllll}\text { chromatography-mass } \quad \text { spectrometry. } J \quad \text { Chromatogr } & A, & 1030, & \text { 77-85. }\end{array}$ http://dx.doi.org/10.1016/j.chroma.2003.11.037 
Blasco, C., Fernandez, M., Pena, A., Lino, C., Silveira, M. I., Font, G., \& Pico, Y. (2003). Assessment of pesticide residues in honey samples from Portugal and Spain. J Agri and Food Chem., 51, 8132-8138. http://dx.doi.org/10.1021/jf034870m

Bogdanov, S. (2006). Contaminants of bee products. Apidologie, 37, 1-18. http://dx.doi.org/10.1051/apido:2005043

Buldini, P. L., Cavalli, S., Mevoli, A., \& Lal Sharma, J. (2001). Ion chromatographic and voltammetric determination of heavy and transition metals in honey. Food Chem, 73, 487-495. http://dx.doi.org/10.1016/S0308-8146(01)00132-7

Chlebo, R. (2006). Bees and Pesticides. Pesticides residues in Food Regulation, Moniotoring, Policy, 23/24 June 2006, Modra-Harmonia, Slovakia.

Choudhary, A., \& Sharma, D. C. (2008). Pesticide residues in honey samples from Himachal Pradesh (India). Bull Environ Contam Toxicol, 80, 417- 425. http://dx.doi.org/10.1007/s00128-008-9426-5

Codex, A. (2001). Draft revised standard for honey. Alinorm 01/25 19-26 December 2001 relating to honey. Off J Europ Comm, L10, 47-52.

Conti, M. E., \& Botrè, F. (2001). Honeybees and their products as potential bioindicators of heavy metals contamination. Environ Monit Assess, 69(3), 267-82. http://dx.doi.org/10.1023/A:1010719107006

Council Directive 2001/110/EC of 20 December 2001 relating to honey. Official Journal of the European Communities 12.1.2002 L 10/48.

Das, Y. K., \& Kaya, S. (2009). Organophosphorus Insecticide Residues in Honey Produced in Turkey. Bull Environ Contam Toxicol, 83, 378-383.

Erbilir, F., \& Erdogrul, O. (2005). Determination of heavy metals in honey in Kahramanmara City, Turkey. Environ Monit Assess, 109, 181-187. http://dx.doi.org/10.1007/s10661-005-5848-2

European Commission Regulation 1999 No. 239/99. Off J Europ Comm, 12.11.1999 L 29, 5.

Food Standards Agency. (2003). Honey Regulations 2003 Guidance Notes.

Frias, I., Rubio, C., Gonzalez-Iglesias, T., Gutierrez, A. J., Gonzalez-Weller, D., \& Hardisson, A. (2008). Metals in Fresh Honeys from Tenerife Island, Spain. Bull Environ Contam Toxicol., 80, 30-33. http://dx.doi.org/10.1007/s00128-007-9301-9

Herrera, A., Perez-Arquillue, C., Conchello, P., Bayarri, S., Lazaro, R., Yagu, C., \& Arino, A. (2005). Determination of pesticides and PCBs in honey by solid-phase extraction cleanup followed by gas chromatography with electron-capture and nitrogen-phosphorus detection. Anal Bioanal Chem, 381, 695-701. http://dx.doi.org/10.1007/s00216-004-2924-3

Joint FAO/WHO. Expert committee on food additives: Summary and conclusions 53 Meeting Rome 1-10 June 1999.

Kabata-Pendias, A. (2004). Soil-plant transfer of trace elements-an environmental issue. Geoderma, 122, 143-149. http://dx.doi.org/10.1016/j.geoderma.2004.01.004

Karise, R., Viik, E., \& Mand, M. (2007). Impact of alpha-cypermethrin on honey bees foraging on spring oilseed rape (Brassica napus) flowers in field conditions. Pest Manag Sci, 63, 1085-1089. http://dx.doi.org/10.1002/ps.1445

Kujawski, M. W., \& Namiesnik, J. (2008). Challenges in preparing honey samples for chromatographic determination of contaminants and trace residues. TrAC-Trends Anal Chem, 27, 785-793. http://dx.doi.org/10.1016/j.trac.2008.07.004

Lambert, O., Piroux, M., Puyo, S., Thorin, C., Larhantec, M., Delbac, F., \& Pouliquen, H. (2012). Bees honey and pollen as sentinels for lead. Environ Pollut, 170, 254-9. http://dx.doi.org/10.1016/j.envpol.2012.07.012

Matei, N., Birghila, S., Dobrinas, S., \& Capota, P. (2004). Determination of C vitamin and some essential trace elements (Ni, Mn, Fe, Cr) in bee products. Acta Chim Slov, 51, 169-175.

Mendes, E., Proença, E. B., Ferreira, I. M., \& Ferreira, M. A. (1998). Quality evaluation of Portuguese honey. Carbohyd Polym, 37, 219-223. http://dx.doi.org/10.1016/S0144-8617(98)00063-0

Mukherjee, I. (2009). Determination of Pesticide Residues in Honey Samples. Bull Environ Contam Toxicol., 83, 818-821. http://dx.doi.org/10.1007/s00128-009-9772-y

Özcan, M. M., \& AL Juhaimi, F, Y. (2011). Determination of heavy metals in bee honey with connected and not 
connected metal wires using inductively coupled plasma atomic emission spectrometry (ICP-AES). Environ Monit Assess, 184(4), 2123-2126.

Perna, A., Simonetti, A., Intaglietta, I., Sofo, A., \& Gambacorta, E. (2012). Metal content of southern Italy honey of different botanical origins and its correlation with polyphenol content and antioxidant activity. International Journal of Food Science and Technology, 47, 1909-1917. $\mathrm{http}: / / \mathrm{dx}$.doi.org/10.1111/j.1365-2621.2012.03050.x

Przybylowski, P., \& Wilenzynka, A. ( 2001). Honey as an environmental marker. Food Chem., 74, 289-291.

Regulation (EU) No 37/2010 of 22 December 2009 on pharmacologically active substances and their classification regarding maximum residue limits in foodstuffs of animal origin. Off $J$ Europ Union $\mathrm{L}$ 15/220.1.2010.

Regulation (EC) No 470/2009 of the European Parliament and of the Council of 6 May 2009. Off J EuropUnion 16.6.2009 L 152/11.

Regulation (EC) No 396/2005 of the European Parliament and of the Council of 23 February 2005 on maximum residue levels of pesticides in or on food and feed of plant and animal origin and amending Council Directive 91/414/EEC. Off J Europ Union 16.3.2005 L 70/1.

Regulation EU 1999 No. 239/99 (Official Journal of the European Union L 290 12.11.1999, p. 5).

Ruschioni, S., Riolo, P., Minuz, R. L., Stefano, M., Cannella, M., Porrini, C., \& Isidoro, N. (2013). Biomonitoring with honeybees of heavy metals and pesticides in nature reserves of the Marche Region (Italy). Biol Trace Elem Res., 154(2), 226-33. http://dx.doi.org/10.1007/s12011-013-9732-6

Schur, A., \& Wallner, K. (2000). Bewertung des individuellen Wirkstoffeintrages von Sammelbienen nach Pestizidapplikation in bluhende Kulturen. Apidologie, 31, 615-616.

Singh, N., \& Bath, P. K. (1997). Quality evaluation of different types of Indian honey. Food Chem., 58, 129-133. http://dx.doi.org/10.1016/S0308-8146(96)00231-2

Stankovska, E., Stafilov, T., \& Šajn, R. (2008). Monitoring of trace elements in honey from the Republic of Macedonia by atomic absorption spectrometry. Environ Monit Assess, 142, 117-126. http://dx.doi.org/10.1007/s10661-007-9913-x

Thompson, H. M. (2010). Risk assessment for honey bees and pesticides - recent developments and 'new issues' Pest Manag Sci, 66, 1157-1162. http://dx.doi.org/10.1002/ps.1994

Tisipi, D., Triantafyllou, M., \& Hiskia, A. (1999). Determination of organochlorine pesticides residues in honey, applying solid phase extraction with RP-C18 material. Analyst, 124, 473-475. http://dx.doi.org/10.1039/a809724k

Tuzen, M., \& Soylak, M. (2005). Trace heavy metal levels in microwave digested honey samples from Middle Anatolia, Turkey. J Food Drug Anal, 1, 343-347.

US-EPA. (2004). Lead and compounds (inorganic). United States Environmental Protection Agency, Washington.

USEPA. (2000). Risk-based Concentration Table. United State Environmental Protection Agency, Washington, DC.

Zhang, J., Gao, H., Peng, B., Li, S., \& Zhou, Z. (2011). Comparison of the performance of conventional, temperature-controlled, and ultrasound-assisted ionic liquid dispersive liquid-liquid microextraction combined with high-performance liquid chromatography in analyzing pyrethroid pesticides in honey samples. J Chromatogr A, 1218, 6621-6629. http://dx.doi.org/10.1016/j.chroma.2011.07.102

Zhu, S. H., Wu, H. L., Li, B. R., Xia, A. L., Han, Q. H., Zhang, Y., .. Yu, R. Q. (2008). Determination of pesticides in honey using excitation-emission matrix fluorescence coupled with second-order calibration and second-order standard addition methods. Anal Chim Acta, 619, 165-172. http://dx.doi.org/10.1016/j.aca.2008.05.005

\section{Copyrights}

Copyright for this article is retained by the author(s), with first publication rights granted to the journal.

This is an open-access article distributed under the terms and conditions of the Creative Commons Attribution license (http://creativecommons.org/licenses/by/3.0/). 